\title{
Association between Retinal Detachment and Cataract Extraction Surgery: A Review
}

\author{
Rodrigo Cortés Arce* \\ Fundación Boliviana de Oftalmologia, Universidad Mayor de San Simón, Bolivia
}

Submission: December 21, 2017; Published: January 22, 2018

*Corresponding author: Rodrigo Cortés Arce, Fundación Boliviana de Oftalmologia, Universidad Mayor de San Simón, Cochabamba, Bolivia, Tel: 5914-4255868; Email: rcortes@fbo-bo.org

\section{Introduction}

Cataract surgery is currently the most performed ambulatory surgery in people over 60 years around the world. Due to its security, precision and previsibility their indication is rising, getting into the refractive field and as an alternative for the presbyopia management.

Retinal Detachment (RD) is one of the most frequent sight-threatening complications of modern cataract surgery and complicates approximately $1 \%$ of all cataract operations performed in developed countries [1-13].

Multiple risk factors are implicated, including patient factors (younger age, male sex, and long axial length) [1-4,8,11,14,15], operative factors (surgical technique, vitreous loss, and posterior capsule rupture), [2,6,11,13,17,19] and postoperative factors (Nd: YAG laser posterior capsulotomy) [4,7]. Operative technique has been implicated as a significant risk factor for subsequent $\mathrm{RD}$, particularly because the abandonment of intracapsular cataract extraction in favor of extracapsular cataract extraction during the late 1970s resulted in a significant decline in the incidence of pseudophakic RD [6,7,12,21,22]. The subsequent adoption of phacoemulsification cataract surgery as the current procedure of choice has maintained this reduced risk for RD $[1,2,7,12]$, despite initial concerns associated with the surgeon learning curve surrounding its adoption [6].

Results of population-based investigations suggest that risk for RD after phacoemulsification may remain increased for 10 years after cataract surgery, yet few studies [1,2] followed up patients longer than approximately 5 years. It was found that the cumulative incidence of RD after phacoemulsification was almost $0.2 \%$ at 1 year. By comparison, the annual incidence of rhegmatogenous RD in the general population of similar age is reported to be between 22 and 49 cases per 100000 population [20,21]. Although these measures are not directly comparable, it suggests a substantially increased risk for RD after phacoemulsification above the baseline risk in the general community.

Revised studies found that the cumulative incidence of RD after phacoemulsification continued to increase up to 10 years after surgery. Long-term follow-up data for cataract surgery outcomes on a population-based level are lacking. A populationbased study with a long follow-up period (20years) by Erie etal. [2] reported that the cumulative incidence of RD after extracapsular cataract extraction (including phacoemulsification) was $0.71 \%$ at 5 years and $1.23 \%$ at 10 years for all the surgical procedures performed between 1980 and 2004. Although their cohort also included patients undergoing extracapsular cataract extraction, the authors reported no significant difference in the probability of RD compared with that associated with phacoemulsification. In contrast, risk for RD in other studies (cumulative incidence, $0.47 \%$ and $0.68 \%$ at 5 and 10 years, respectively) was substantially lower than that reported by these authors.

Many studies [2,6,11,13,17,18,22] demonstrated an increased risk for RD (range, 4.5-19.9 times higher) after surgical procedures documenting posterior capsule rupture with or without vitreous loss, although a few studies $[1,4,23]$ found no change in risk. Anterior vitrectomy is generally performed only in cataract surgery in which a posterior capsule rupture has occurred with vitreous loss. Similarly, failed IOL insertion would occur in situations of complicated surgery in which capsule support is compromised. Both events could be regarded as a surrogate marker for complicated surgery involving posterior capsule rupture and vitreous loss. These findings highlight the importance of close follow-up monitoring in patients whose cataract surgery has been complicated by posterior capsule rupture because of significant risk for RD that may extend many years after surgery.

In other study, patients younger than 60 years undergoing phacoemulsification were almost 4 times more likely to have an RD compared with those who were 60 years or older. Several theories have been postulated for why younger patients are more likely to experience RD following phacoemulsification. One relates to vitreous changes after cataract surgery. Ripandelli et al. [15] found that posterior vitreous detachment occurred following cataract surgery in $75.8 \%$ of patients without a history of posterior vitreous detachment or lattice degeneration. Given that $10 \%$ to $15 \%$ of posterior vitreous detachment occurrences are associated with a retinal tear, older patients may be protected from posterior vitreous detachment because they are more likely 


\section{JOJ Ophthalmology}

to have already had phakic posterior vitreous detachment, which tends to occur in individuals 60 years or older [15,24]. Younger eyes are also more likely to be abnormal in their development of cataract (e.g. traumatic cataract), and this may predispose these eyes to pseudophakic RD.

Compared with women, men undergoing phacoemulsification were almost twice as likely to have an RD. The increased risk for RD in men has been reported elsewhere. In a populationbased cohort similar to ours, Sheu et al. [1] found that men had a 2.43 times higher risk for RD after phacoemulsification than women. Although men were younger on average than women, the observed sex difference remained after adjusting for age. Sex differences in the anatomy of the eye and vitreous have been postulated as potential contributing factors. Men tend to have longer axial length [24], while women tend toward earlier posterior vitreous detachment [25]. This may confer a protective effect on women for subsequent RD after cataract surgery. Men may also be more likely to experience traumatic injury or to engage in activities where eye trauma is more likely owing to their occupation or lifestyle, placing them at higher risk for pseudophakic RD.

Additional important risk factors for RD after cataract surgery identified in other studies include axial length and the use of Nd:YAG posterior capsulotomy. Axial length of at least 25 $\mathrm{mm}$ has been significantly associated with increased relative risk for RD after cataract surgery, approaching 6 times that of eyes with shorter axial length $[14,15]$. In their populationbased study, Ninn-Pedersen \& Bauer [4] found that for every 1-mm increase in axial myopia, the associated relative risk for RD was 1.3. Similarly, Nd:YAG laser posterior capsulotomy was associated with increased risk for RD, with a relative risk of 4.9 documented in their study [4].

\section{Conclusion}

In conclusion, the incidence of pseudophakic RD has declined markedly since the adoption of phacoemulsification cataract surgery. As identified in previous studies, it is confirmed that younger patient age and male sex are important risk factors for subsequent RD. Complicated operations necessitating anterior vitrectomy carry significantly increased risk for RD. Knowledge about the importance of such risk factors is very important. The surgeon experience, size of incision, anterior chamber stability are important variables that are not fully understood and how they affect in the production of RD post phacoemulsification.

\section{References}

1. Sheu SJ, Ger LP, Chen JF (2007) Male sex as a risk factor for pseudophakic retinal detachment after cataract extraction in Taiwanese adults. Ophthalmology 114(10): 1898-1903.

2. Erie JC, Raecker MA, Baratz KH, Schleck CD, Burke JP, et al. (2006) Risk of retinal detachment after cataract extraction, 1980-2004: a population-based study. Ophthalmology 113(11): 2026-2032.

3. Norregaard JC, Thoning H, Andersen TF, Bernth-Petersen P, Javitt JC, et al. (1996) Risk of retinal detachment following cataract extraction results from the International Cataract Surgery Outcomes Study. Br J Ophthalmol 80(8): 689-693.

4. Ninn-Pedersen K, Bauer B (1996) Cataract patients in a defined Swedish population, 1986 to 1990, V: postoperative retinal detachments. Arch Ophthalmol 114(4): 382-386.

5. Javitt JC, Street DA, Tielsch JM, Wang Q, Kolb MM, et al. (1994) Cataract Patient Outcomes Research Team. National outcomes of cataract extraction: retinal detachment and endophthalmitis after outpatient cataract surgery. Ophthalmology 101(1): 100-106.

6. Javitt JC, Vitale S, Canner JK, Krakauer H, McBean AM, et al. (1991) National outcomes of cataract extraction, I: retinal detachment after inpatient surgery. Ophthalmology 98(6): 895-902.

7. Olsen G, Olson RJ (2000) Update on a long-term, prospective study of capsulotomy and retinal detachment rates after cataract surgery. J Cataract Refract Surg 26(7): 1017-1021.

8. Boberg-Ans G, Henning V, Villumsen J, la Cour M (2006) Long-term incidence of rhegmatogenous retinal detachment and survival in a defined population undergoing standardized phacoemulsification surgery. Acta Ophthalmol Scand 84(5): 613-618

9. Russell M, Gaskin B, Russell D, Polkinghorne PJ (2006) Pseudophakic retinal detachment after phacoemulsification cataract surgery: tenyear retrospective review. J Cataract Refract Surg 32(3): 442-445.

10. Ozbek Z, Saatci AO, Durak I, Gunenc U, Kaynak S (2007) Phacoemulisification and intraocular lens implantation in eyes with long axial length. Ann Ophthalmol (Skokie) 39(3): 217-221.

11. Szijártó Z, Schvöller M, Pótó L, Kuhn F, Kovács B (2007) Pseudophakic retinal detachment after phacoemulsification. Ann Ophthalmol (Skokie) 39(2): 134-139.

12. Clark A, Morlet N, Ng JQ, Preen DB, Semmens JB (2011) Wholepopulation trends in complications of cataract surgery over 22 years in Western Australia. Ophthalmology 118(6): 1055-1061.

13. Desai P, Minassian DC, Reidy A (1999) National cataract surgery survey 1997-8: a re- port of the results of the clinical outcomes. Br J Ophthalmol 83(12): 1336-1340.

14. Sheu SJ, Ger LP, Ho WL (2010) Late increased risk of retinal detachment after cataract extraction. Am J Ophthalmol 149(1): 113-119.

15. Ripandelli G, Coppé AM, Parisi V, Olzi D, Scassa C, et al. (2007) Posterior vitreous detachment and retinal detachment after cataract surgery. Ophthalmology 114(4): 692-697.

16. Chitkara DK, Smerdon DL (1997) Risk factors, complications, and results in extracapsular cataract extraction. J Cataract Refract Surg 23(4): 570-574

17. Tuft SJ, Minassian D, Sullivan P (2006) Risk factors for retinal detachment after cataract surgery: a case-control study. Ophthalmology 113(4): 650-656.

18. Bhagat N, Nissirios N, Potdevin L, Chung J, Lama P, et al. (2007) Complications in resident-performed phacoemulsification cataract surgery at New Jersey Medical School. Br J Ophthalmol 91(10): 13151317

19. Polkinghorne PJ, Craig JP (2004) Northern New Zealand Rhegmatogenous Retinal Detachment Study: epidemiology and risk factors. Clin Experiment Ophthalmol 32(2): 159-163.

20.Li XX, Beijing Rhegmatogenous, Retinal Detachment Study Group (2003) Incidence and epidemiological characteristics of rhegmatogenous retinal detachment in Beijing, China. Ophthalmology $110(12):$ 2413-2417

21. Jakobsson G, Montan P, Zetterberg M, Stenevi U, Behndig A, et al. (2009] Capsule complication during cataract surgery: retinal detachment after cataract surgery with capsule complication: Swedish Capsule Rupture 
Study Group re- port 4. J Cataract Refract Surg 35(10): 1699-1705.

22. Smith PW, Stark WJ, Maumenee AE, Enger CL, Michels RG, et al. (1987) Retinal detachment after extracapsular cataract extraction with posterior chamber intraocular lens. Ophthalmology 94(5): 495-504.

23. Coppe' AM, Lapucci G. Posterior vitreous detachment and retinal detachment following cataract extraction. CurrOpinOphthalmol. 2008;19(3):239-242.
24. Fotedar R, Wang JJ, Burlutsky G, et al. Distribution of axial length and ocular biometry measured using partial coherence laser interferometry (IOL Master) in an older white population. Ophthalmology. 2010;117(3):417-423.

25. Hayreh SS, Jonas JB. Posterior vitreous detachment: clinical correlations. Ophthalmologica. 2004;218(5):333-343.

\section{Your next submission with Juniper Publishers will reach you the below assets}

- Quality Editorial service

- Swift Peer Review

- Reprints availability

- E-prints Service

- Manuscript Podcast for convenient understanding

- Global attainment for your research

- Manuscript accessibility in different formats

( Pdf, E-pub, Full Text, Audio)

- Unceasing customer service

Track the below URL for one-step submission https://juniperpublishers.com/online-submission.php 